\title{
Localizing and Achieving the Sustainable Development Goals at the National Level: Cases of Leadership ${ }^{1}$
}

\author{
T. Lanshina, V. Barinova, A. Loginova, E. Lavrovsky, I. Ponedelnik
}

Tatiana Lanshina - PhD, Senior Research Associate, Centre for Economic Modelling of Energy and Environment, Russian Presidential Academy of National Economy and Public Administration (RANEPA); SDSN Youth in Russia. 82/1 Prospect Vernadskogo, Moscow, 119571, Russian Federation; E-mail: lanshina@ranepa.ru

Vera Barinova - PhD, Deputy Director, Centre for Economic Modelling of Energy and Environment, Russian Presidential Academy of National Economy and Public Administration (RANEPA); SDSN Russia; 82/1 Prospect Vernadskogo, Moscow, 119571, Russian Federation; E-mail: barinova@ranepa.ru

Arina Loginova - Student, the Faculty of Foreign Regional Studies and Regional Administration, the Institute of Public Administration and Civil Service, Russian Presidential Academy of National Economy and Public Administration (RANEPA); Ambassador of SDSN Youth in Russia; 82/1 Prospect Vernadskogo, Moscow, 119571, Russian Federation; E-mail: log-arina@yandex.ru

Evgenii Lavrovskii - Student, the Faculty of Applied Economics and Commerce, MGIMO; Ambassador of SDSN Youth in Russia; 82/1 Prospect Vernadskogo, Moscow, 119571, Russian Federation; E-mail: lavrovskii.evgenii@gmail.com

Irina Ponedelnik - ICTSD Junior Researcher; Ambassador of SDSN Youth in Russia; International Environment House 2, Chemin de Balexert 7-9, 1219 Geneva, Switzerland; E-mail: irponedelnik@ gmail.com

\begin{abstract}
This article describes the experience of localization and implementation of the Sustainable Development Goals (SDGs) at the national level in the 10 countries which top the global SDG Index compiled by the Sustainable Development Solutions Network (SDSN) and the Bertelsmann Stiftung. The authors apply methods of comparative and content analysis of national and international documents and conclude that leading countries began to work actively on the transition toward sustainable development more than a decade ago, established effective inter-ministerial coordination in this area and have achieved significant success. Nevertheless, even they are still far from the full implementation of the SDGs. Moreover, not all of them have localized Agenda 2030 within their national sustainable development strategies.

The authors identify three key SDG localization and implementation schemes: full localization (e.g. Germany), implementation of the SDGs without their formal localization (e.g. Sweden) and the complete absence of localization (e.g. Finland). The most preferable and effective scheme, according to the authors, is the first one.

In the late 1990s, Russia could have become one of the pioneers of sustainable development. However, due to insufficient political will, Russia is still at the initial stages of its transition toward sustainable development. In order to catalyze progress in this area, Russia needs to urgently develop and adopt a national sustainable development strategy in which all of the SDGs are localized, take into account SDGs in other key strategic documents and set specific quantitative goals and designate ministries that will be responsible for achieving these goals.
\end{abstract}

${ }^{1}$ The editorial board received the article in May 2018. 
Key words: Sustainable Development Goals (SDGs); Agenda 2030; localization of SDGs

For citation: Lanshina T., Barinova V., Loginova A., Lavrovsky E., Ponedelnik I. (2019) Localizing and Achieving the Sustainable Development Goals at the National Level: Cases of Leadership. International Organisations Research Journal, vol. 14, no 1, pp. 207-224 (in English). DOI: 10.17323/1996-7845-2019$01-12$

\section{Introduction}

The conceptualization of sustainable development as well as a broad international discussion on this issue began in the 1970s. In 1987, in its famous report, the Brundtland Commission elaborated the classic definition of sustainable development as development that "meets the needs of the present without compromising the ability of future generations to meet their own needs" [WCED, 1987]. This definition is focused on intergenerational and environmental issues as it contains a clear message that present generations need to save natural resources for their descendants. In 2000, the United Nations (UN) Millennium Declaration was adopted at the UN Millennium Summit. In 2001 eight Millennium Development Goals (MDGs) were derived from this document, focusing international efforts on solving social and economic problems in the world's poorest countries. Environmental risks were also reflected among the MDGs: the seventh goal ("Ensure environmental sustainability") was fully devoted to them, although the main focus of the agenda was still on the social and economic aspects of development.

The Millennium Development Goals were designed to improve the quality of life in developing countries by 2015. As a result of their implementation, profound and positive change was created. Between 1990 and 2015, the number of people with an income of less than $\$ 1.25$ a day more than halved, decreasing from 1.9 to 0.8 billion people. The proportion of people who suffer from malnutrition declined from 23.3\% in 1990-1992 to $12.9 \%$ in $2014-2016$. The number of children who do not attend school was halved during the period 2000-2015. The maternal mortality rate in 1990-2015 also was almost halved, with the major reduction recorded after 2000. Since 1990, more than two billion people have gained access to improved sanitation facilities. The proportion of the urban population living in slums decreased from $39.4 \%$ in 2000 to $29.7 \%$ in 2014 [UN, 2015a]. However, absolute indicators sometimes showed completely opposite (i.e. negative) trends. For example, while the proportion of the urban population living in slums decreased, the total number of slum dwellers in 2000-2015 increased from 792 to 881 million people [UN, 2015a]. The key social problems of humanity (hunger, extreme poverty, inequality) were not fully resolved either. In 2015, almost half of employed people worked in vulnerable conditions. The environment continued to deteriorate due to irresponsible economic activities. Therefore, after the expiration of the Millennium Development Goals, humanity needed new mechanisms to continue the transition toward sustainable development. 
Eight MDGs comprising 21 targets were replaced by 17 Sustainable Development Goals (SDGs) and 169 targets. tThe SDGs were set in Resolution 70/1 of the United Nations General Assembly "Transforming Our World: The 2030 Agenda for Sustainable Development" (hereinafter referred to as Agenda 2030). This document was adopted by 193 UN member states in September 2015 [UN, 2015b]. Like the MDGs, the SDGs were designed for a period of 15 years but, unlike the MDGs, the SDGs are absolutely relevant for both developed and developing countries. Implementation of SDGs involves a very wide range of stakeholders, such as governments, the research community, businesses (especially transnational corporations) and civil society. Among these stakeholders, it is young people and youth organizations who play a special role, since today's young people will live and take decisions in the world created after 2030.

In Agenda 2030, finally, all three aspects of sustainable development - economic, social and environmental - were harmonized to the extent that 193 countries could negotiate. Agenda 2030 is essentially the key to solving all global problems, from extreme poverty and armed conflicts to gender inequality and climate change. With time, the intergenerational aspect has almost disappeared in sustainable development discourse. At present, it is considered that sustainable development "offers a framework to generate economic growth, achieve social justice, exercise environmental stewardship and strengthen governance" [UN Secretary-General, 2013], following an integrated holistic approach that reflects the modern definition of sustainable development.

The global process to implement the SDGs has been going on for more than two years, and this allows us to take stock of the initial progress at global, national and local levels. This article examines the implementation of SDGs at the national level in several leading countries, since it is states that take key decisions which significantly influence regions and local communities, as well as determine national contributions to global efforts on hunger and poverty eradication, combating climate change and introducing pollution control.

The purpose of this paper is to identify and synthesize national approaches to the localization and implementation of the Sustainable Development Goals in countries that are world leaders in sustainable development. The authors use content analysis of national and international documents, as well as comparative analysis. The main sources are voluntary national reviews (VNRs) of progress in the implementation of Agenda 2030 and national sustainable development strategies. Since Russia has not yet begun the process of localization and implementation of the SDGs, the findings obtained by the authors can be extremely useful for the strategic planning of sustainable development in Russia.

\section{National Frameworks for Sustainable Development}

In this paper, the top 10 countries on the 2018 SDG Index compiled by the Sustainable Development Solutions Network (SDSN) and the Bertelsmann Stiftung [Bertelsmann Stiftung, SDSN, 2018] are considered leaders in the localization and implementa- 
tion of the SDGs. The SDG Index ranks countries according to how close they are to achieving sustainable development goals (from 0 which is worst to 100 which is best); the first place is occupied by the country with the maximum number of points and the last by the country with the minimum. It should be noted that the SDG Index has some shortcomings. For example, it is calculated on the basis of publicly available statistical data, which at present are far from complete. Also, criticism by some experts is related to the fact that in addition to official data, this rating also uses estimates from research centres and non-governmental organizations. Due to changes in methodology, SDG Index scores are not comparable across 2016, 2017 and 2018 reports. In addition, while it is worthwhile to compare the scores of the SDG Index with scores of ratings compiled by other research teams, so far there is only one index tracking all 17 SDGs in all countries of the world with available statistics.

The top 10 countries on the SDG Index include only Scandinavian and other European countries: Sweden, Denmark, Finland, Germany, France, Norway, Switzerland, Slovenia, Austria and Iceland. Their level of SDG achievement ranges from $79.7 \%$ (Iceland) to $85.0 \%$ (Sweden). Thus, even these countries are still quite far from full SDG implementation. Moreover, even these leaders are not on track to achieve the SDGs by 2030 and their progress in achieving the most problematic goals for them (SDG12 "Responsible Consumption and Production" and SDG13 "Fighting Climate Change") remains insufficient.

Top 10 SDG Index performers are the pioneers of sustainable development. They contributed much at the UN Conference on Environment and Development in Rio de Janeiro in 1992 (known as the Earth Summit), which resulted in the adoption of Agenda 21, as well as in the development and adoption of the UN Millennium Declaration in 2000.

Many of these countries are leading developing aid donors. Denmark, Switzerland and Sweden, along with Great Britain and Luxembourg, which occupy the 14th and 22nd places respectively in the SDG Index [Bertelsmann Stiftung, SDSN, 2018], form a small circle of countries that have been regularly allocating over $0.7 \%$ of their gross national income (GNI) to official development assistance (ODA) in line with UN recommendations [UN HLPF, 2017b]. Since 2006, Sweden has spent about $1 \%$ of its GNI on ODA annually. According to data from the Organisation for Economic Co-operation and Development (OECD), in the 2000s, even Development Assistance Committee (DAC) members devoted only about $0.3 \%$ of their GNI to ODA [OECD, 2018].

In countries occupying leading positions in the SDG index, sustainable development is more or less incorporated into the educational process. In 2003, the Swedish government formed a committee on education for sustainable development. In 2006, in one of its communications, the Swedish government stated that the concept of sustainable development should be studied at all levels of the educational process [Gustafsson, Engström, Svenson, 2015]. Currently, sustainable development is taught in Sweden from kindergarten to adult education. In Finland, sustainable development 
was introduced into school education in 2003-2004. The country also took actions to integrate the concept of sustainable development into education in kindergartens and in educational programs for adults. In Austria, ecology, human health, civil rights and gender equality are included in the curriculum on an interdisciplinary basis, and when possible they are part of specific subjects.

The abbreviation ESD, which stands for Education for Sustainable Development, has come into use. It became popular during the UN Decade of Education for Sustainable Development (2005-2014). However, despite the significant progress achieved by top 10 SDG Index performers in the educational process, in many cases much depends on the educational organization and its willingness to take action [Buckler, Creech, 2014]. In addition, in many cases, educational programs have a strong focus on environmental issues with little attention to social and economic aspects of sustainability.

Thus, by the time Agenda 2030 was adopted, the countries under review had gained significant experience in sustainable development. They actively participated in the conceptualization of this phenomena, provided development aid to the world's poorest countries, and integrated sustainable development into their educational processes, which significantly increased the awareness and support. This largely explains why these countries are leading global sustainable development.

\section{National Sustainable Development Strategies}

Since sustainable development practices of different countries vary greatly, all of the SDGs and corresponding targets of Agenda 2030 are formulated in a very generalized form, and specific quantitative targets are usually absent. It is assumed that each country should localize SDGs - that means, it should choose from among the 169 global goals those that should be achieved at the national level by 2030, taking into account national development priorities and financial capacities. These goals should be adapted to national conditions (i.e. reformulated) and, if possible, states should define corresponding statistical indicators and set quantitative targets for each goal. Goals and specific quantitative targets should be reflected in national strategic documents.

Countries have very different implementation practices for the SDGs. Switzerland adopted its first sustainable development strategy in 1997 (Table 1). Since then, the document has been revised every four years and the fifth edition is in effect from 2016-2019. Most other leaders of sustainable development adopted their first strategies in the early 2000s - Austria, Germany, Denmark, Iceland, Norway and Sweden did this in 2002 (Table 1). Their documents have been also revised several times.

Many countries have already made adjustments to their sustainable development strategies after the adoption of Agenda 2030 (Table 1). For example, Germany has renewed its strategy of sustainable development, and each of the 17 SDGs has at least one corresponding goal in the new German strategy. German goals are clearly set and adapted for the national context and each of them has an indicator to assess progress. For example, target 7.2 in Agenda 2030 ("By 2030, increase substantially the share of 
renewable energy in the global energy mix") corresponds to indicator 7.2.1 ("Renewable energy share in the total final energy consumption"). In the German sustainable development strategy, this corresponds to targets 7.2.a ("Share of renewable energy sources in gross final energy consumption to be increased to $18 \%$ by 2020 , to $30 \%$ by 2030 and $60 \%$ by 2050") and 7.2.b ("Share of renewable energy sources in gross electricity consumption to be increased to at least $35 \%$ by 2020 , to at least $50 \%$ by 2030 , to at least $65 \%$ by 2040 and to at least $80 \%$ by 2050 "). It should be noted that in this case the German strategy has revised the SDG indicator "The share of renewable energy sources in gross final energy consumption" to "The share of electricity from renewable sources in gross energy consumption."

Similarly, Switzerland has localized all 17 SDGs in its own nine goals and 52 targets. The monitoring of implementation of selected goals and objectives in Switzerland will be carried out with the MONET indicator system established in 2003 to monitor sustainable development. In the near future, this system will be significantly expanded and adapted to Agenda 2030.

Slovenia, like Germany and Switzerland, has formulated its own 12 goals which cover all 17 global SDGs. These 12 goals in their turn relate to five areas (Table 1). Also, Slovenia has already selected 30 statistical indicators to track the achievement of SDGs. The ultimate goal of implementation of Slovenia's sustainable development strategy to 2030 is to ensure a high standard of living for all.

Some countries have already achieved much in the sphere of sustainable development, and did not revise their strategies or formally localize the SDGs. The most prominent examples are Sweden and Norway. Sweden adopted an action plan to implement Agenda 2030 focused on achieving social and gender equality, sustainable development of communities, creating a circular economy, strengthening businesses and corporate social responsibility, improving sustainability of the food system and stimulating innovations. In 2017, Sweden also published its first voluntary national review of the implementation of Agenda 2030. Norway included the SDGs in its budget process and released the first voluntary national review in 2016. In addition, each ministry is responsible for a follow-up on its respective SDGs. The coordinating ministry - the Ministry of Finance - is responsible for progress on all 17 SDGs.

Denmark also did not formally localize the SDGs and only announced five priority SDGs - 5, 7, 13, 16 and 17 - to which the majority of other countries cannot yet pay enough attention. In 2017, Denmark published the first voluntary national report on implementation of Agenda 2030. Denmark also announced its intention to actively cooperate with other countries on sustainable development, distinguishing the following three groups of countries: poor and vulnerable countries, poor and stable countries and transitional and emerging markets. The funds that Denmark will allocate for cooperation will be directed mainly to the first and second groups.

Some countries such as France and Iceland have still to update their sustainable development strategies. Others, such as Finland, have formally updated their strategies but retained all former priorities and added an analysis of the SDGs these priorities 


\begin{tabular}{|c|c|c|c|}
\hline 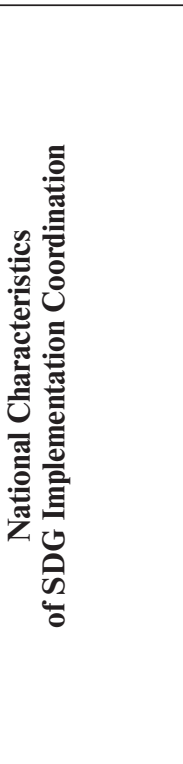 & 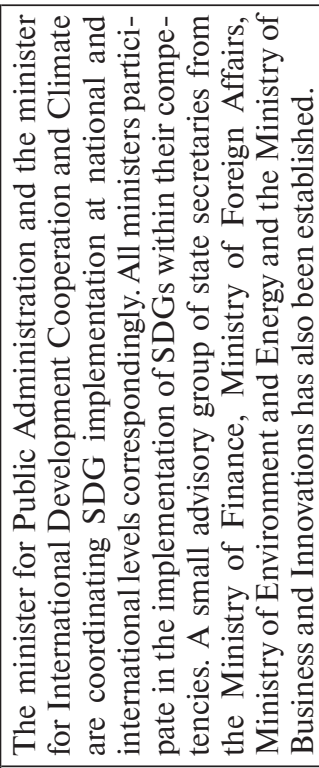 & 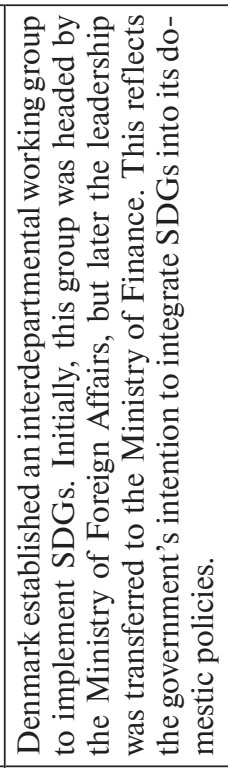 & 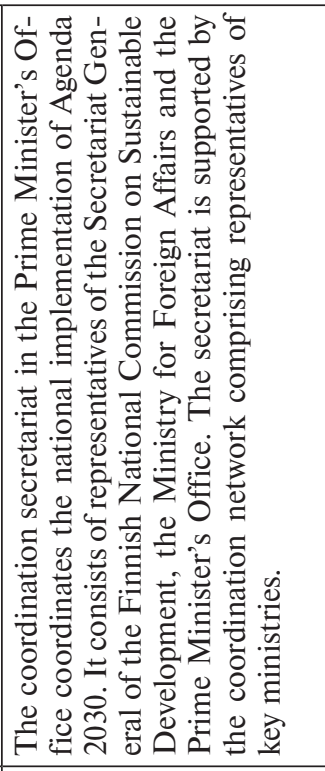 \\
\hline 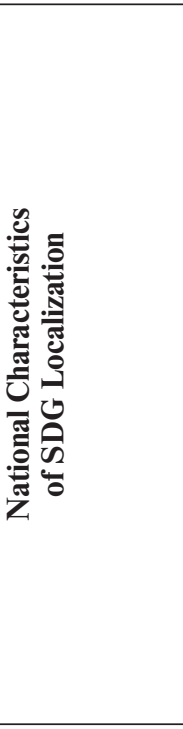 & 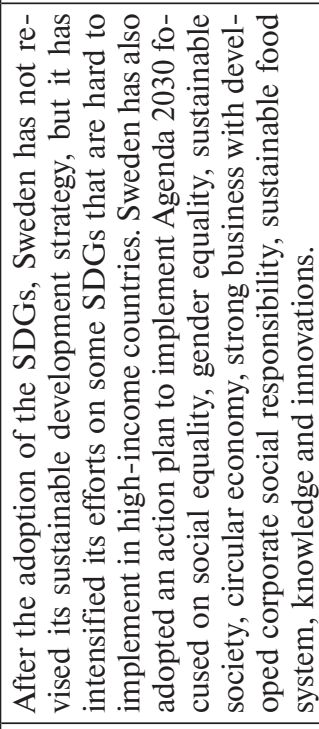 & 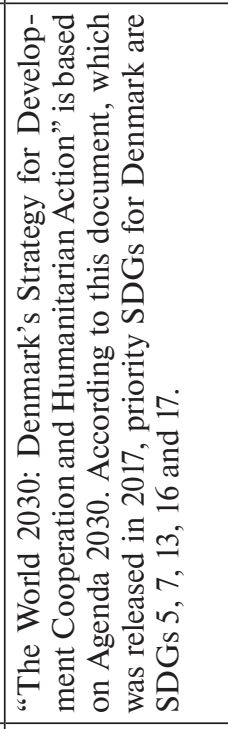 & 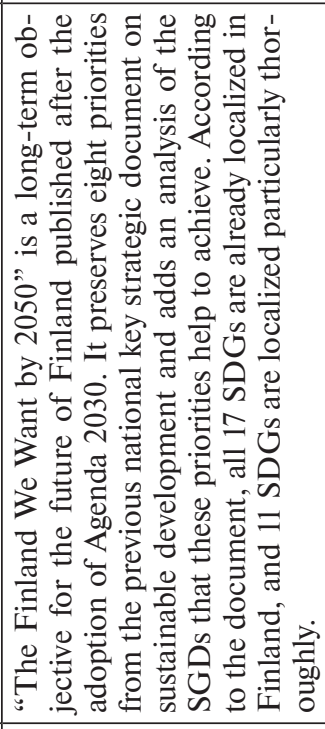 \\
\hline 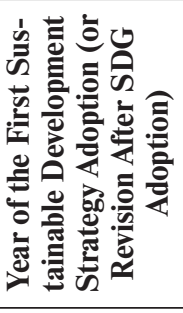 & 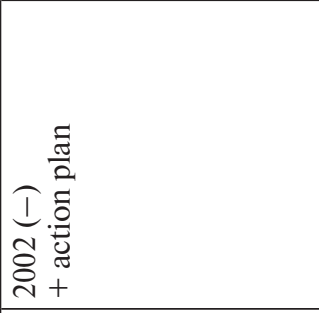 & 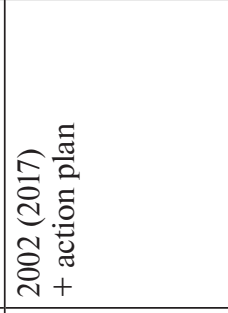 & 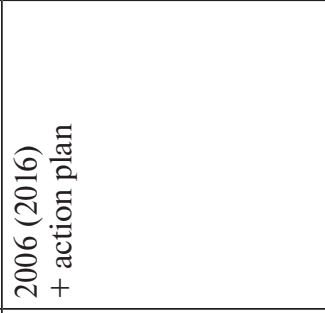 \\
\hline है & 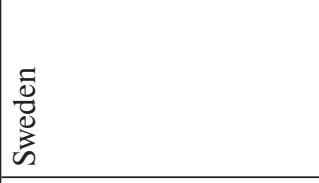 & 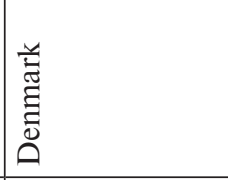 & $\begin{array}{l}\vec{\Xi} \\
\frac{\Xi}{\Xi} \\
\text { 吉 }\end{array}$ \\
\hline 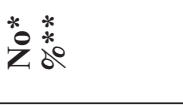 & $\begin{array}{r}0 \\
0 \\
-\infty \\
-\infty\end{array}$ & 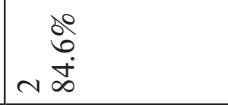 & $\begin{array}{l}\dot{\delta} \\
\dot{0} \\
m \\
\infty\end{array}$ \\
\hline
\end{tabular}




\begin{tabular}{|c|c|c|c|c|}
\hline 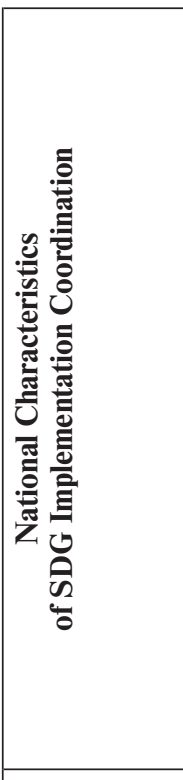 & 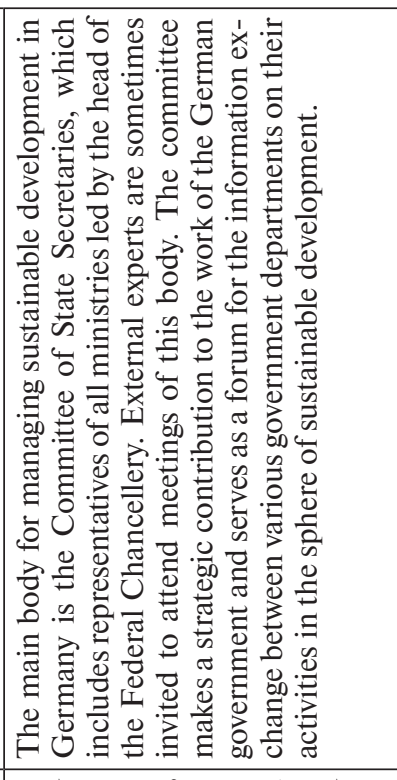 & 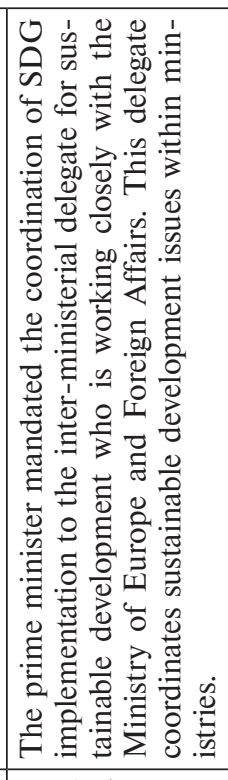 & 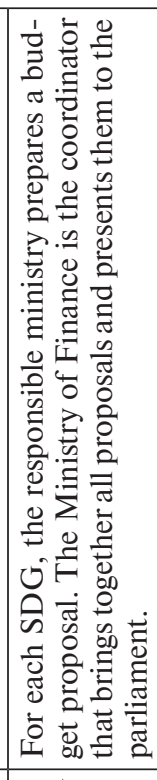 & 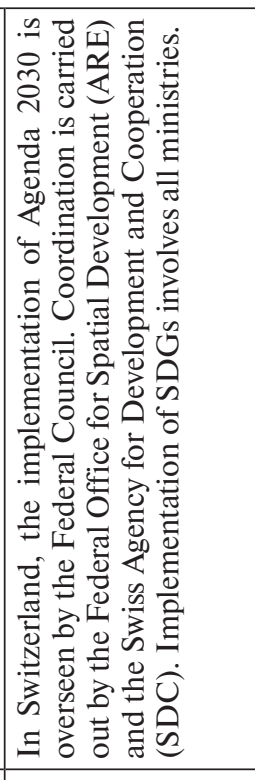 \\
\hline 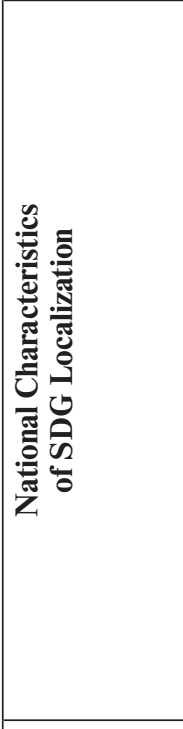 & 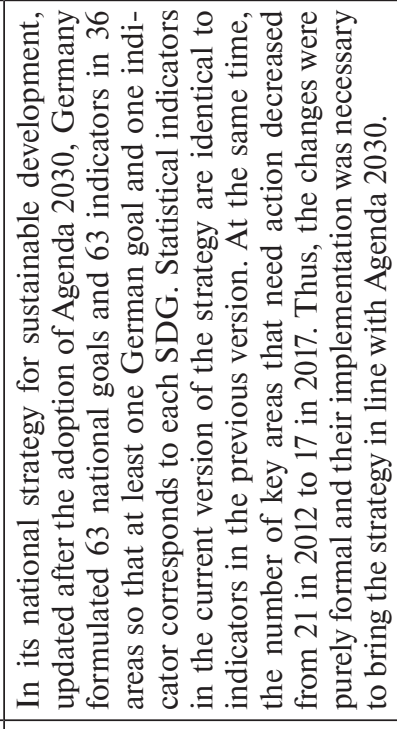 & 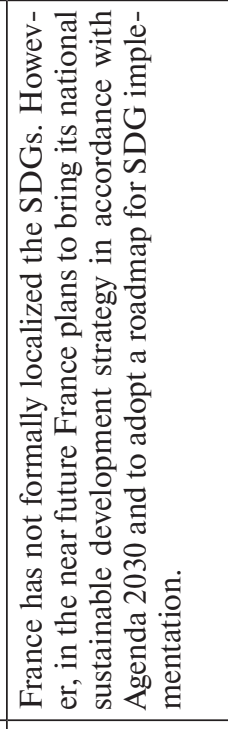 & 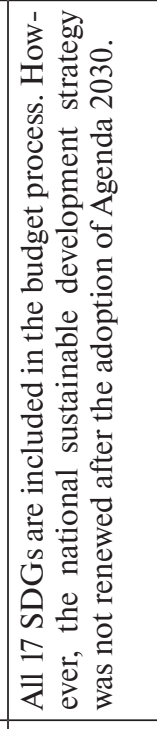 & 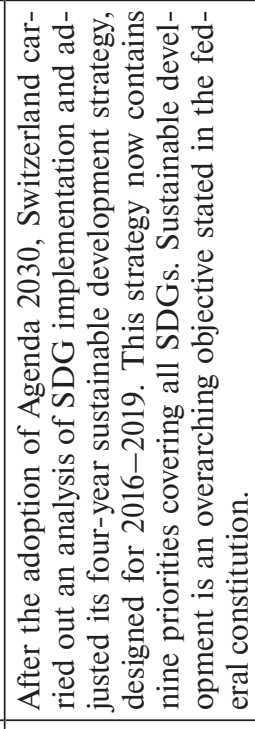 \\
\hline 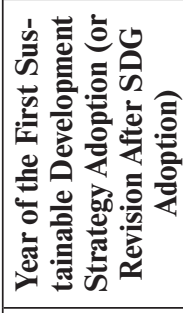 & 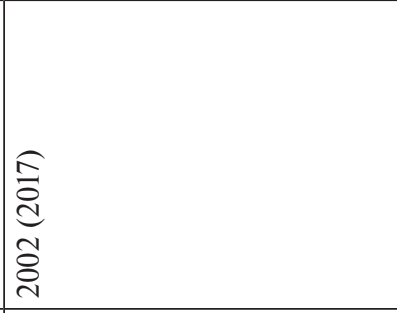 & 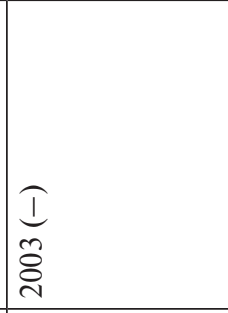 & 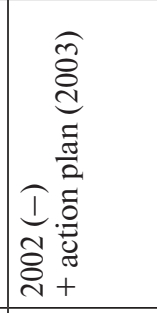 & 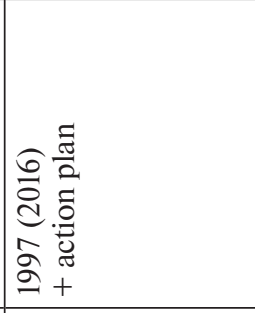 \\
\hline है & 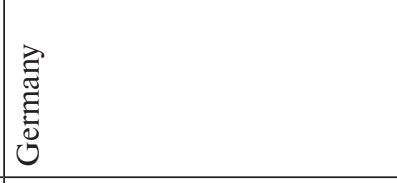 & 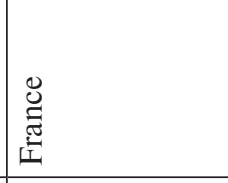 & 芳 & 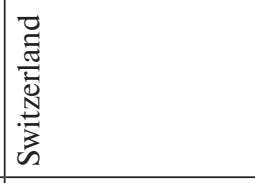 \\
\hline $\begin{array}{l}* \\
* \\
z^{*}\end{array}$ & $\begin{array}{r}\infty \\
\stackrel{\infty}{i} \\
+\infty\end{array}$ & in & ํำ & $\begin{array}{r}30 \\
-\infty \\
-\infty\end{array}$ \\
\hline
\end{tabular}




\begin{tabular}{|c|c|c|c|c|c|c|}
\hline 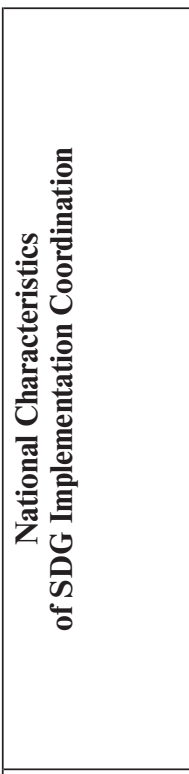 & 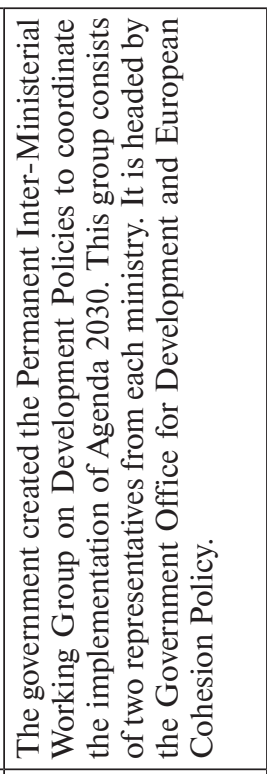 & 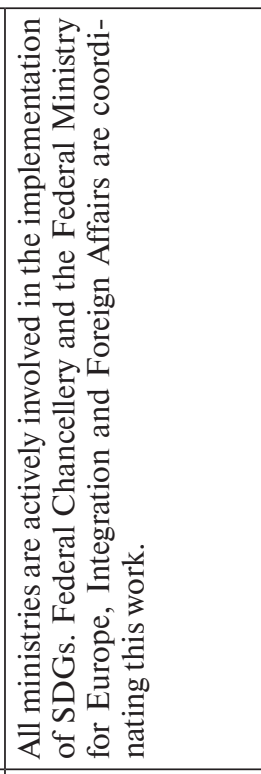 & 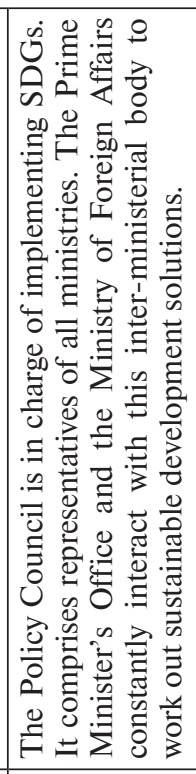 & 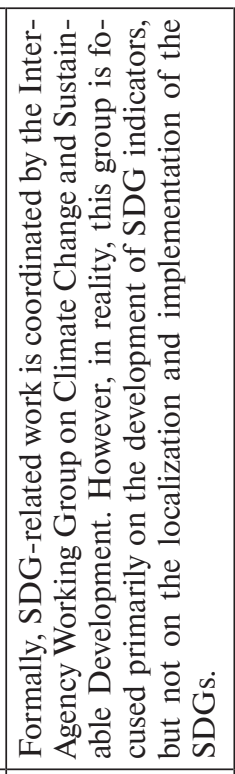 & 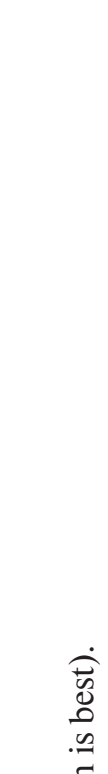 & 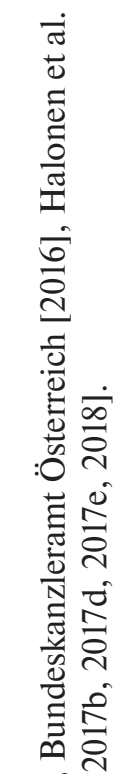 \\
\hline 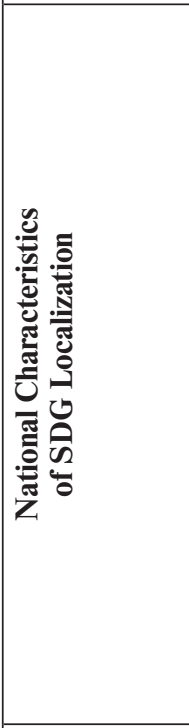 & 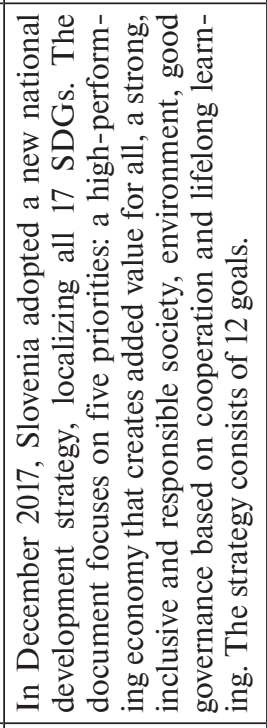 & 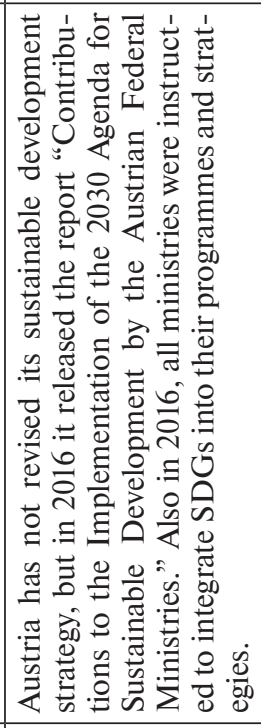 & 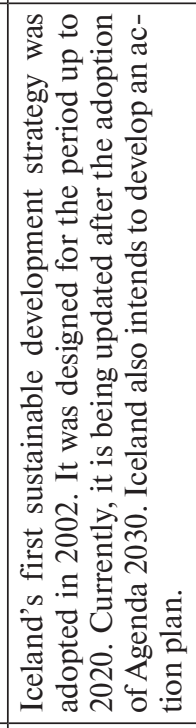 & 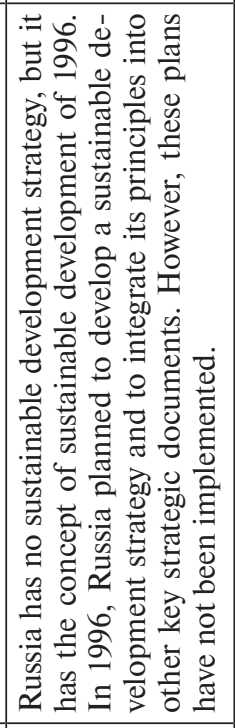 & 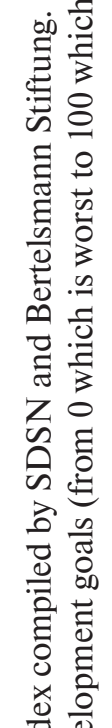 & 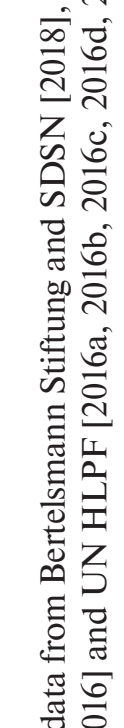 \\
\hline 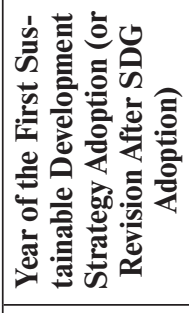 & 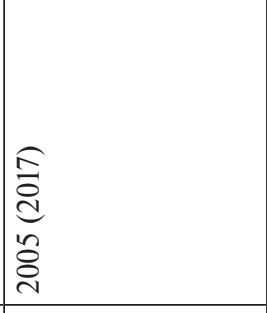 & 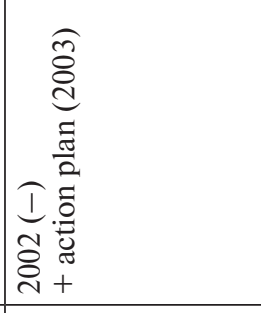 & $\begin{array}{l}\text { I } \\
\text { İ } \\
\stackrel{\text { dे }}{ }\end{array}$ & & 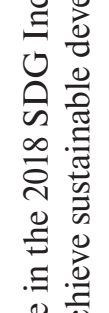 & 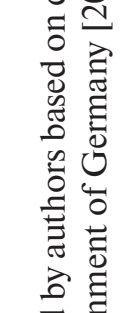 \\
\hline 昱 & $\begin{array}{l}\frac{a}{0} \\
\frac{\partial}{0} \\
\frac{\partial}{\omega}\end{array}$ & 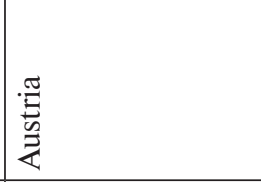 & 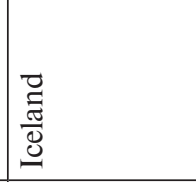 & 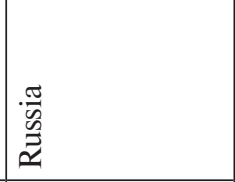 & 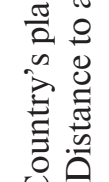 & 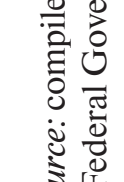 \\
\hline$\hat{z}^{*} \dot{0}^{*}$ & $\begin{array}{r}0 \\
0 \\
\infty \\
\infty \\
\infty\end{array}$ & $\begin{array}{r}\dot{0} \\
0 \\
0 \\
0\end{array}$ & 웅 & 官 & & 홍 \\
\hline
\end{tabular}


help to achieve. The updated strategy of Finland states that the country has already localized all 17 SDGs, and 11 of them have been localized very thoroughly. Neither France, nor Iceland, nor Finland have yet issued any voluntary national report on the implementation of Agenda 2030.

Another interesting example of SDG localization (in fact, an example of absent localization) is demonstrated by Austria. The country has not yet revised its sustainable development strategy. However, in 2016 all ministries were tasked to include SDGs in their programmes and strategies, as well as to develop new action plans to implement Agenda 2030 where necessary. In 2017, Austria released the report "Outline 2016: Contributions to the Implementation of the 2030 Agenda for Sustainable Development by the Austrian Federal Ministries" which contains a detailed analysis of the country against each SDG. No voluntary national report on Austria has been published so far.

Based on the experience of top 10 SDG performers, three schemes for SDG localization can be distinguished. The first scheme can be called "deep localization." It implies a thorough consideration of the global sustainable development goals at the national level and the setting of national goals very close to the SDGs. Such national goals cover all SDGs. This approach is found in Germany, Switzerland and Slovenia.

The second scheme is SDG implementation without formal localization, which is typical of Sweden, Norway and Denmark. These countries are actively implementing Agenda 2030 and reporting to the international community on this, but they have not updated their sustainable development strategies after the adoption of Agenda 2030.

The third scheme of SDG localization stands apart from Agenda 2030 and in fact represents no localization. This scheme is found in France, Iceland, Finland and Austria. These countries are either still updating their sustainable development strategies and planning to develop road maps, or they have already done so but have made no changes so far.

\section{Sustainable Development Governance}

Global governance through inclusive goal setting is considered to be one of the main Agenda 2030 innovations. At least 70 governments and a large number of civil society representatives took part in the process of elaborating the SDGs [Bierman, Kanie, Kim, 2017]. In this regard, SDGs are fundamentally different from MDGs, since the latter offered the same goals for all developing countries which were defined by the UN Secretariat to a large extent. On the one hand, SDGs give countries more freedom and allow them to fully adapt the global agenda to their own specifics and priorities. But on the other hand, this sets a complex task for countries, since translating global goals into national ones requires wellfunctioning national governance systems [Bierman, Kanie, Kim, 2017].

In fact, the principle of soft governance or governance based on goals and commitments formulated by countries themselves lies at the basis of the implementation of the SDGs. Recent years have seen a steady increase in the popularity of this principle, especially in cases when global governance affects sensitive areas of national interest [Lanshina, Barinova, 2017]. 
Another innovation of Agenda 2030 is that it implies a detailed assessment of countries on the basis of a large number of quantitative indicators. This idea first appeared in the Agenda 21 document in 1992. In 1995, the UN Commission on Sustainable Development presented the first set of indicators for sustainable development and afterwards a number of countries developed their own sets [Rinne, Lyytimäki, Kautto, 2013]. For example, Sweden presented its first set of sustainable development indicators in 2001. This set consisted of 30 indicators classified into four topics - efficiency, equality/participation, adaptability and values and resources for future generations. Switzerland established its MONET monitoring system (German: Monitoring der nachhaltigen Entwicklung) consisting of 75 sustainable development indicators in 2003. Austria has been publishing MONE reports on sustainable development monitoring (German: Monitoring für eine nachhaltige Entwicklung) since 2006. These reports contain 26 key indicators supplemented by another 56 . Other top SDG-performing countries have similar systems. In Russia, the first system of sustainable development monitoring is currently being created.

Since many countries outside the top 10 SDG performers list still do not collect statistics on many environmental and social indicators, the introduction of Agenda 2030 will certainly become an incentive to develop sustainable development statistics as well as to monitor relevant indicators. It is necessary to highlight the fundamental importance of having a developed monitoring system in sustainable development governance: in the absence of clear quantitative targets and mechanisms for their monitoring, Agenda 2030 and its implementation become an abstract task, as well as strategic management in general.

The role of national coordination mechanisms also cannot be underestimated in the implementation of Agenda 2030. As follows from Table 1, an inter-ministerial committee headed by a ministry is usually responsible for coordinating the implementation of the SDGs. In Sweden, Austria and Germany, absolutely all ministries are involved in the process of SDG implementation. In other countries such as Finland, Slovenia and Switzerland, only ministries that have a direct relation to sustainable development are involved in this work.

Some countries give particular importance to sustainable development. Thus, the Federal Chancellery is responsible for sustainable development in Germany [Federal Government of Germany, 2016]. In Switzerland, the need for transition to sustainable development is set in the federal constitution [UN HLPF, 2018a]. The coordination of SDG localization and implementation may be the responsibility of the Minister of State Service (Sweden), the Ministry of Finance (Denmark and Norway) or the Federal Agency for Spatial Development (Switzerland). This indicates a significant difference in emphasis of sustainable development management practices in the world.

\section{SDGs and Russia}

As a member of UN, Russia participated in the elaboration and adoption of the Sustainable Development Goals. Despite this, SDG implementation is not a priority in Russia, and in fact it has not yet begun with the exception of those SDG indicators that 
are being developed by the Federal State Statistics Service of the Russian Federation (Rosstat). Russia is a member of the UN Conference of European Statisticians' (CES) Steering Group on Statistics for Sustainable Development Goals.

However, the progress in statistics on sustainable development is also not sufficient. At the moment, datasets on many statistical indicators are unavailable. Also the federal statistical works plan includes SDG indicators, but these are mainly social development indicators. A large number of datasets on environment, institutions, and responsible production and consumption are not being developed.

It is important to note that Russia could become one of the pioneers of sustainable development. In 1996, Russia was among the first to approve the concept of sustainable development. According to this concept, Russia was to develop a national strategy of sustainable development as early as 1996, when the majority of today's leaders did not have such strategies. However, further work in this area stopped and the strategy was never adopted. In 2012, coordination of sustainable development was formally assigned to the Interdepartmental Working Group on Climate Change and Sustainable Development that is part of the Presidential Administration. However, in the sphere of sustainable development, the efforts of this working group have been predominantly focused on the development of statistical indicators. In addition, the group is headed by the advisor to the president and special presidential representative on climate issues (until recently, Alexander Bedritsky, since 2018 - Ruslan Edelgeriyev). In the top SDG-performing countries such groups are usually headed by ministries.

Many of the Agenda 2030 objectives overlap with the national priorities set in Russia's key strategic documents, such as Presidential Decree No 204 "On the National Goals and Strategic Objectives of the Development of the Russian Federation for the Period up to 2024" of 7 May 2018, the message of the president of the Russian Federation to the Federal Assembly, the forecast of the long-term socio-economic development of the Russian Federation for the period up to 2030, as well as the strategy for the socio-economic development of the Russian Federation up to 2035 (is being developed). These documents also address social problems, environmental degradation, governance shortcomings and the challenges of economic growth and development. However, they lack an integrated holistic approach toward development aimed at achieving stable economic growth without negative consequences for the environment or without reinforcing social and gender inequality. All key strategic Russian documents remain focused on steady economic progress (i.e. GDP growth) and extensive development through the intense exploitation of natural resources. In addition, they do not contain references to Agenda 2030 and do not mention the SDGs - that is, they are completely outside of the international discussion on development and Agenda 2030.

In order to integrate into this international discussion and begin a real transition toward sustainability, Russia needs to adopt its national sustainable development strategy and localize key Agenda 2030 provisions within it, as well as integrate localized SDGs into existing national strategic documents. In addition, it is advisable to define ministries responsible for achieving specific quantitative targets and introducing key 
performance indicators (KPI) based on the achievement of these targets for the relevant ministers. Similar work needs to be done at the regional level (at the level of the regional and city administrations).

It is necessary to intensify the efforts of the Interdepartmental Working Group on Climate Change and Sustainable Development on issues related to sustainable development. This group should be responsible for elaboration of a sustainable development strategy and for implementation of sustainable development principles in other key national strategic documents. It is crucial that the interdepartmental working group not only coordinates this work among representatives of ministries related to sustainable development, but also involves in its discussions representatives of regional and municipal authorities, as well as representatives of business, universities, NGOs and other stakeholders. The transition toward sustainable development and the implementation of Agenda 2030 should become a priority for the president of the Russian Federation.

\section{Conclusion}

This article analyses the experience of the localization and implementation of Sustainable Development Goals by top SDG-performing countries according to the SDG Index compiled by SDSN and the Bertelsmann Stiftung. The authors conclude that even this narrow group of countries has very different experiences both in the transition toward sustainable development and in SDG implementation. Some countries adopted national sustainable development strategies in the 1990s, others did so only in the early 2000s. Countries also undergo completely different stages of implementing SDGs in strategic documents - from no localization to the localization of all 17 goals. All countries under review have already developed mechanisms to coordinate SDG implementation. Such mechanisms are represented by inter-ministerial groups comprising representatives of various ministries.

SDG Index leaders have been implementing the principles of sustainable development for many years (usually more than 15) and they have also developed coordinating mechanisms for SDG implementation headed by agencies within the executive branch. At the same time, not all of them have localized the SDGs in their national sustainable development strategies and not all have adjusted their strategies after the adoption of Agenda 2030 - e.g. the Scandinavian countries. This does not mean that Scandinavian countries stay idle on the SDGs; these countries have already implemented a significant part of Agenda 2030 (up to 85\%) and they are global leaders in this sphere. Still, Scandinavian countries need to localize the SDGs, which had been elaborated for all countries of the world, including the most developed and top performing ones.

The authors identify three main schemes for SDG localization and implementation among the top performers on the SDG Index: deep localization (countries set their own goals based on Agenda 2030), SDG implementation without their formal localization (implementation of Agenda 2030 without amendments to the national strategies of sustainable development) and a complete absence of localization (countries continue 
to make efforts in the sphere of sustainable development without references to Agenda 2030 in their national strategic documents). The first scheme is typical of Germany, Switzerland and Slovenia, the second of Sweden, Norway and Denmark and the third of France, Iceland, Finland and Austria. According to the authors, the most desirable scheme is deep localization of the SDGs.

Russia is still at the very beginning of its transition toward sustainable development, although it had a chance to become a world leader as one of the first countries to adopt the concept of sustainable development in 1996. Considering the rapid progress of other countries and the great international experience accumulated in this area, Russia needs to develop its national sustainable development strategy as soon as possible, localize Agenda 2030 within it and include the SDGs in all other key strategic documents. In other words, it should choose the deep localization pathway. Doubtless, Rosstat should continue to improve statistics in the sphere of sustainable development, and the Interdepartmental Working Group on Climate Change and Sustainable Development should be given the task of localizing and implementing SDGs in Russia. The latter should regularly discuss progress on SDG localization in Russia, come out with specific proposals and interact with regional and municipal authorities, as well as cooperate at the international level within its competences.

\section{References}

Bertelsmann Stiftung, Sustainable Development Solutions Network (SDSN) (2018) Global Responsibility: Implementing the Goals. SDG Index and Dashboards Report 2018. Available at: http://www.sdgindex.org/assets/files/2018/01\%20SDGS\%20GLOBAL\%20EDITION\%20WEB\%20V8\%20060718.pdf (accessed 13 June 2018).

Bierman F., Kanie N., Kim R.E. (2017) Global Governance by Goal-Setting: The Novel Approach of the UN Sustainable Development Goals. Current Opinion in Environmental Sustainability, vol. 26-7, pp. 26-31.

Buckler C., Creech H. (2014) Shaping the Future We Want: UN Decade of Education for Sustainable Development (2005-2014): Final Report. Available at: http://unesdoc.unesco.org/ images/0023/002303/230302e.pdf (accessed 13 November 2018).

Bundeskanzleramt Österreich (2016) Beiträge der Bundesministerien zur Umsetzung der Agenda 2030 für nachhaltige Entwicklung durch Österreich. Available at: https://www.bundeskanzleramt.gv.at/documents/131008/510106/Agenda2030_BF.pdf/b5006e54-a458-4f83-bd1a-7a4ca611aba7 (accessed 17 January 2019).

Federal Government of Germany (2016) German Sustainable Development Strategy: New Version. Available at: https://www.bundesregierung.de/Content/DE/_Anlagen/Nachhaltigkeit/2017-06-20-nachhaltigkeit-neuauflage-engl.pdf?_blob=publicationFile \&v=2 (accessed 11 July 2018).

Gustafsson P., Engström S., Svenson A. (2015) Teachers' View of Sustainable Development in Swedish Upper Secondary School. Procedia: Social and Behavioral Sciences, vol. 167, pp. 7-14.

Halonen M., Persson Å., Sepponen S., Kehler Siebert C., Bröckl M., Vaahtera A., Quinn S., Trimmer C., Isokangas A. (2017) Sustainable Development Action: The Nordic Way: Implementation of the Global 2030 Agenda for Sustainable Development in Nordic Cooperation. Nordic Council of Ministers. Available at: https://norden.diva-portal.org/smash/get/diva2:1092868/FULLTEXT01.pdf (accessed 13 June 2018).

Lanshina T., Barinova V. (2017) Global Governance for Renewable Energy: International Trends and Russia. International Organisations Research Journal, vol. 12, no 1, pp. 110-126. 
Organisation for Economic Co-operation and Development (OECD) (2018) Net ODA. Available at: https://data.oecd.org/oda/net-oda.htm (accessed 8 July 2018).

Rinne J., Lyytimäki J., Kautto P. (2013) From Sustainability to Well-Being: Lessons Learned From the Use of Sustainable Development Indicators at National and EU Level. Ecological Indicators, vol. 35, pp. 35-42.

United Nations (UN) (2015a) Millennium Development Goals: 2015 Report. Available at: http://www. un.org/millenniumgoals/2015_MDG_Report/pdf/MDG\%202015\%20rev\%20(July\%201).pdf (accessed 16 May 2018). (In Russian)

United Nations (UN) (2015b) Transforming our World: The 2030 Agenda for Sustainable Development. Available at: https://sustainabledevelopment.un.org/post2015/transformingourworld/publication (accessed 17 January 2017).

United Nations High-Level Political Forum on Sustainable Development (UN HLPF) (2016a) Voluntary National Review Report on the Implementation of Sustainable Development Goals, Finland. Available at: https://sustainabledevelopment.un.org/index.php?page $=$ view\&type $=30022 \& n r=64 \& \mathrm{me}$ nu $=3170$ (accessed 7 July 2018).

United Nations High-Level Political Forum on Sustainable Development (UN HLPF) (2016b) Voluntary National Review Report on the Implementation of Sustainable Development Goals, France. Available at: https://sustainabledevelopment.un.org/content/documents/10726Report\%20SDGs\%20France. pdf (accessed 7 July 2018).

United Nations High-Level Political Forum on Sustainable Development (UN HLPF) (2016c) Voluntary National Review Report on the Implementation of Sustainable Development Goals, Germany. Available at: https://sustainabledevelopment.un.org/content/documents/10686HLPF-Bericht_final_ EN.pdf (accessed 12 July 2018).

United Nations High-Level Political Forum on Sustainable Development (UN HLPF) (2016d) Voluntary National Review Report on the Implementation of Sustainable Development Goals, Norway. Available at: https://sustainabledevelopment.un.org/content/documents/10692NORWAY\%20HLPF\%20 REPORT\%20-\%20full\%20version.pdf (accessed 12 July 2018).

United Nations High-Level Political Forum on Sustainable Development (UN HLPF) (2017b) Report for the Voluntary National Review. Denmark's Implementation of the 2030 Agenda for Sustainable Development. Available at: https://sustainabledevelopment.un.org/content/documents/16013Denmark. pdf (accessed 12 June 2018).

United Nations High-Level Political Forum on Sustainable Development (UN HLPF) (2017d) Voluntary National Review Report on the Implementation of Sustainable Development Goals, Slovenia. Available at: https://sustainabledevelopment.un.org/content/documents/16313Slovenia.pdf (accessed 12 July 2018).

United Nations High-Level Political Forum on Sustainable Development (UN HLPF) (2017e) Voluntary National Review Report on the Implementation of Sustainable Development Goals, Sweden. Available at: https://sustainabledevelopment.un.org/content/documents/16033Sweden.pdf (accessed 11 July 2018).

United Nations High-Level Political Forum on Sustainable Development (UN HLPF) (2018) Voluntary National Review Report on the Implementation of Sustainable Development Goals, Switzerland. Available at: https://sustainabledevelopment.un.org/content/documents/10617Full\%20Report\%20HLPF\%20 2016_Switzerland_EN\%20fin.pdf (accessed 11 July 2018).

United Nations (UN) Secretary-General (2013) Secretary-General's Remarks at a G20 Working Dinner on "Sustainable Development for All." St. Petersburg, 5 September. Available at: https://www.un.org/sg/ en/content/sg/statement/2013-09-05/secretary-generals-remarks-g20-working-dinner-sustainable (accessed 16 May 2018).

World Commission on Environment and Development (WCED) (1987) Our Common Future. Available at: http://www.un-documents.net/our-common-future.pdf (accessed 12 May 2018). 


\title{
Опыт локализации и внедрения Целей устойчивого развития в странах - лидерах в данной сфере ${ }^{1}$
}

\author{
Т.А. Ланьшина, В.А. Баринова, А.Д. Логинова, Е.П. Лавровский, \\ И.В. Понедельник
}

Ланьшина Татьяна Александровна - к.э.н., научный сотрудник Центра экономического моделирования энергетики и экологии Российской академии народного хозяйства и государственной службы при Президенте РФ (РАНХиГС); координатор молодежного отделения международной Сети по поиску решений в сфере устойчивого развития SDSN Youth в России; Российская Федерация, 119571, Москва, просп. Вернадского, д. 82, стр. 1; E-mail: lanshina@ranepa.ru

Баринова Вера Александровна - к.э.н., заместитель директора Центра экономического моделирования энергетики и экологии Российской академии народного хозяйства и государственной службы при Президенте РФ (РАНХиГС); менеджер международной Сети по поиску решений в сфере устойчивого развития SDSN в России; Российская Федерация, 119571, Москва, просп. Вернадского, д. 82, стр. 1; E-mail: barinova@ranepa.ru

Логинова Арина Дмитриевна - студентка факультета международного регионоведения и регионального управления Института государственной службы и управления (ИГСУ) Российской академии народного хозяйства и государственной службы при Президенте РФ (РАНХиГС); посол молодежного отделения международной Сети по поиску решений в сфере устойчивого развития SDSN Youth в России; Российская Федерация, 119571, Москва, просп. Вернадского, д. 82, стр. 1; E-mail: log-arina@yandex.ru

Лавровский Евгений Павлович - студент факультета прикладной экономики и коммерции МГИМО МИД России; посол молодежного отделения международной Сети по поиску решений в сфере устойчивого развития SDSN Youth в России; Российская Федерация, 119454, Москва, просп. Вернадского, д. 76; Е-таil: lavrovskii.evgenii@gmail.com

Понедельник Ирина Валентиновна - младший сотрудник ICTSD; посол молодежного отделения международной Сети по поиску решений в сфере устойчивого развития SDSN Youth в России; International Environment House 2, Chemin de Balexert 7-9, 1219 Geneva, Switzerland; E-mail: irponedelnik@gmail.com

В статье рассмотрен опыт локализации и внедрения Целей устойчивого развития на национальном уровне в странах ТОП-10 Индекса ЦУР, составленного SDSN и Bertelsmann Stiftung. Использован метод сравнительного анализа и метод контент-анализа национальных и международных документов. Авторы пришли к выводу, что страны - лидеры устойчивого развития уже более десяти лет ведут активную работу по переходу к устойчивому развитию, наладили межведомственную координацию в данной сфере и добились значительных успехов. Тем не менее и они пока далеки от полной реализации ЦУР. При этом далеко не все из них локализовали Повестку 2030 в своих национальных стратегиях устойчивого развития.

Авторы выявили три ключевых схемы локализации и имплементации ЦУР: полная локализация (пример Германия), имплементация ЦУР без их формальной локализации (пример - Швеция) и полное отсутствие локализации (пример - Финляндия). Наиболее желательной представляется первая схема.

В коние 1990-х годов Россия могла стать одним из пионеров устойчивого развития. Ввиду недостаточной политической воли она до сих пор находится на начальных этапах перехода к устойчивому развитию. Для активизации работы в данной сфере России необходимо срочно разработать и принять национальную стратегию устойчивого развития и локализовать в ней все ЦУР, включить ЦУР во все прочие стратегические документы, а также поставить конкретные количественные цели и назначить министерства, которые будут отвечать за достижение этих иелей.

\footnotetext{
${ }^{1}$ Статья поступила в редакцию в мае 2018 г.
} 
Ключевые слова: Цели устойчивого развития (ЦУР); Повестка 2030; локализация ЦУР

Для цитирования: Ланьшина Т.А., Баринова В.А., Логинова А.Д., Лавровский Е.П., Понедельник И.В. (2019) Опыт локализации и внедрения Целей устойчивого развития в странах - лидерах в данной сфере // Вестник международных организаций. T. 14. № 1. C. 207-224. DOI: 10.17323/1996-7845-2019-01-12

\section{Источники}

Ланьшина Т.А., Баринова В.А. (2017) Глобальное управление в сфере возобновляемой энергетики: международные тенденции и Россия // Вестник международных организаций. Т. 12. № 1. С. $110-126$.

ООН (2015a) Цели развития тысячелетия: доклад за 2015 год. Режим доступа: http://www.un.org/ru/ millenniumgoals/mdgreport2015.pdf (дата обращения: 16.05.2018).

ООН (2015b) Преобразование нашего мира: Повестка дня в области устойчивого развития на период до 2030 года. Режим доступа: https://documents-dds-ny.un.org/doc/UNDOC/GEN/N15/285/75/PDF/ N1528575.pdf?OpenElement (дата обращения: 16.05.2018).

Ban Ki-moon (2013) Secretary-General's Remarks at a G20 working Dinner on "Sustainable Development for All. Режим доступа: https://www.un.org/sg/en/content/sg/statement/2013-09-05/secretary-generalsremarks-g20-working-dinner-sustainable (дата обращения: 16.05.2018).

Bertelsmann Stiftung, SDSN (2018) SDG Index and Dashboards Report 2018. Режим доступа: http://www. sdgindex.org/assets/files/2018/01\%20SDGS\%20GLOBAL\%20EDITION\%20WEB\%20V8\%20060718.pdf (дата обращения: 13.06.2018).

Bierman F., Kanie N., Kim R.E. (2017) Global Governance by Goal-setting: the Novel Approach of the UN Sustainable Development Goals // Current Opinion in Environmental Sustainability. Vol. 26-27. P. $26-31$.

Bundeskanzleramt Österreich (2016) Beiträge der Bundesministerien zur Umsetzung der Agenda 2030 für nachhaltige Entwicklung durch Österreich. Режим доступа: http://archiv.bka.gv.at/DocView.axd?CobId=65724 (дата обращения: 13.07.2018).

DESD (2014) Shaping the Future We Want, DESD Final Report. Режим доступа: http://unesdoc.unesco. org/images/0023/002303/230302e.pdf (дата обращения: 13.11.2018).

Gustafsson P., Engström S., Svenson A. (2015) Teachers’ View of Sustainable Development in Swedish Upper Secondary School // Procedia - Social and Behavioral Sciences. Vol. 167. P. 7-14.

Nordic Council of Ministers (2017) Sustainable Development Action - the Nordic Way. Режим доступа: https://norden.diva-portal.org/smash/get/diva2:1092868/FULLTEXT01.pdf (дата обращения: 13.06.2018).

OECD (2018) Net ODA. Режим доступа: https://data.oecd.org/oda/net-oda.htm (дата обращения: 08.07.2018).

Rinne J., Lyytimäki J., Kautto P. (2013) From Sustainability to Well-being: Lessons Learned from the Use of Sustainable Development Indicators at National and EU Level // Ecological Indicators. Vol. 35. P. $35-42$.

The Federal Government of Germany (2016) German Sustainable Development Strategy. Режим доступа: https://www.bundesregierung.de/Content/DE/_Anlagen/Nachhaltigkeit/2017-06-20-nachhaltigkeit-neuauflage-engl.pdf?_blob=publicationFile\&v=2 (дата обращения: 11.07.2018).

UN HLPF (2016a) Voluntary National Review Report on the Implementation of Sustainable Development Goals, Finland. Режим доступа: https://sustainabledevelopment.un.org/index.php?page=view\&type=30022 $\& n r=64 \& m e n u=3170$ (дата обращения: 07.07.2018).

UN HLPF (2016b) Voluntary National Review Report on the Implementation of Sustainable Development Goals, France. Режим доступа: https://sustainabledevelopment.un.org/content/documents/10726Report\%20 SDGs\%20France.pdf (дата обращения: 07.07.2018).

UN HLPF (2016c) Voluntary National Review Report on the Implementation of Sustainable Development Goals, Germany. Режим доступа: https://sustainabledevelopment.un.org/content/documents/10686HLPFBericht_final_EN.pdf (дата обращения: 12.07.2018). 
UN HLPF (2016d) Voluntary National Review Report on the Implementation of Sustainable Development Goals, Norway. Режим доступа: https://sustainabledevelopment.un.org/content/documents/10692NORWAY\%20 HLPF\%20REPORT\%20-\%20full\%20version.pdf (дата обращения: 12.07.2018).

UN HLPF (2017b) Report for the Voluntary National Review. Denmark's Implementation of the 2030 Agenda for Sustainable Development. Режим доступа: https://sustainabledevelopment.un.org/content/ documents/16013Denmark.pdf (дата обращения: 12.06.2018).

UN HLPF (2017d) Voluntary National Review Report on the Implementation of Sustainable Development Goals, Slovenia. Режим доступа: https://sustainabledevelopment.un.org/content/documents/16313Slovenia. pdf (дата обращения: 12.07.2018).

UN HLPF (2017e) Voluntary National Review Report on the Implementation of Sustainable Development Goals, Sweden. Режим доступа: https://sustainabledevelopment.un.org/content/documents/16033Sweden. pdf (дата обращения: 11.07.2018).

UN HLPF (2018) Voluntary National Review Report on the Implementation of Sustainable Development Goals, Switzerland. Режим доступа: https://sustainabledevelopment.un.org/content/documents/10617Full\%20Report\%20HLPF\%202016_Switzerland_EN\%20fin.pdf (дата обращения: 11.07.2018).

WCED (1987) Our Common Future. Режим доступа: http://www.un-documents.net/our-common-future. pdf (дата обращения: 12.05.2018). 